\title{
Súbeh disciplinárneho konania a trestného konania proti sudcovi ${ }^{1}$
}

\author{
Čentéš, J., Beleš, A.*
}

ČENTÉŠS, J., BELEŠ, A.: Súbeh disciplinárneho konania a trestného konania proti sudcovi. Právny obzor, 104, 2021, č. 1, $39-53$.

Concurrence of disciplinary and criminal proceedings against judge. In the article, the authors pay attention to the clarification of the principle of ne bis in idem in terms of the concurrence of disciplinary proceedings and criminal proceedings in relation to the sanctioning of a judge for the same act. They focus mainly on the decision-making activities of the European Court of Human Rights, the Slovak and Czech courts. At the end of the article, they express their own opinions on the possibility of optional cessation of criminal prosecution of a judge after he was sanctioned for the same act in disciplinary proceedings.

Key words: disciplinary proceedings, criminal proceedings, concurrence, Ne bis in idem, disciplinary authority, court

\section{1 Úvod}

Zásada ne bis in idem, ktorú možno preložit' ako nie dvakrát o tom istom (v totožnej veci), zakazuje dvojité stíhanie, súdenie alebo potrestanie za totožný skutok, totožnej osoby, ${ }^{2}$ pričom jej zmyslom je dosiahnut', aby osoba bola za jeden skutok sankcionovaná len raz. Aplikovanie zásady ne bis in idem medzi právnymi odvetviami navzájom je predmetom rozsiahlych polemík ${ }^{3}$ a mnohých nejasností a je aj jadrom predkladaného článku. Uvedenú zásadu možno skúmat' pri súbehu viacerých trestných konaní, pri súbehu viacerých správnych konaní, ale aj pri súbehu správneho a trestného konania a opačne, či pri súbehu konaní medzi verejnoprávnymi (trestnými, resp. správnymi) konaniami a súkromnoprávnymi konaniami sankčného charakteru. ${ }^{4}$

* Prof. JUDr. Jozef Č e n t é š, PhD., Právnická fakulta, Univerzita Komenského v Bratislave, Generálna prokuratúra Slovenskej republiky;

Andrej B e 1 e š, JUDr., PhD., Právnická fakulta, Univerzita Komenského v Bratislave.

${ }^{1}$ Článok je podporený Agentúrou na podporu výskumu a vývoja na základe zmluvy č. APVV-19-0102 Efektívnost' prípravného konania - skúmanie, hodnotenie, kritériá a vplyv legislatívnych zmien.

${ }^{2}$ Podrobnejšie pozri Franz Fischer proti Rakúsku z 29. mája 2001, č. 37950/97, a Sergey Zolotukhin proti Rusku z 10. februára 2009, č. 14939/03.

${ }^{3}$ Pozri napr. ČENTÉŠ, J. Súbeh trestného konania a daňového konania a zásada ne bis idem. In Justičná revue, roč. 69, 2017, č. 6-7, s. 757 - 779; BELEŠ, A. Uplatňovanie zásady ne bis in idem v disciplinárnom konaní vo výkone väzby a výkone trestu - kazuistický pohl'ad. In Policajná teória a prax, roč. 25, 2017, č. 3, s. 81 - 95, BELEŠ, A. Uplatňovanie zásady ne bis in idem pri disciplinárnych konaniach príslušníkov ozbrojených bezpečnostných zborov. Zborník z medzinárodnej vedeckej konferencie doktorandov a mladých vedeckých pracovníkov Míl'niky práva v stredoeurópskom priestore 2017, organizovanej Univerzitou Komenského v Bratislave, Právnickou fakultou, v dňoch 30. 3. - 1. 4. 2017, s. 684 - 691.

${ }^{4}$ Typickým príkladom sú disciplinárne konania v rámci občianskych združení, najmä takých pri ktorých hrozba sankcie, ktorú možno uložit’ prevyšuje maximálne výšky trestnoprávnych sankcií a pre dotknutú osobu môže byt' z hl'adiska postihu podstatne závažnejšia. Tak napríklad doživotný zákaz výkonu športovej činnosti 
Vo verejnej mediálnej i odbornej diskusii sa - v súvislosti s podozreniami z korupčného správania niektorých sudcov ${ }^{5}$ - problematickým bodom javí súbeh disciplinárneho konania a trestného konania vo vzt’ahu k sankcionovaniu sudcov za totožný skutok. Vyžadujú si princípy ochrany základných práv a slobôd ochranu jednotlivca - sudcu pred trestným konaním (stíhaním), ak bol za totožný skutok postihnutý disciplinárne? Odpoved'ou je bližší rozbor rozhodovacej činnosti Európskeho súdu pre l’udské práva (d’alej len ESLPP), slovenských a českých súdov a nadväzujúcej právnej úpravy.

\section{Ne bis in idem z pohl'adu Dohovoru}

Zásada ne bis in idem ustanovená v čl. 4 Protokolu č. 7 Dohovoru o ochrane l'udských práv a základných slobôd (d’alej Dohovor), znie: „Nikoho nemožno stíhat' alebo potrestat'v trestnom konani podliehajúcom právomoci toho istého štátu za trestný čin, za ktorý už bol oslobodený alebo odsúdený konečným rozsudkom podl'a zákona a trestného poriadku tohto štátu. “ Pri autonómnom výklade pojmu trestné konanie ${ }^{7}$ chápaniu tohto pojmu v slovenskom jazyku zodpovedajú termíny trestný čin aj priestupok, resp. porušenie zákona kvalifikované bud' ako priestupok, alebo ako trestný čin.

$Z$ týchto dôvodov sa vnútroštátne uplatňovanie ${ }^{8}$ zásady ne bis in idem nevzt'ahuje len na trestné konania $v$ zmysle Trestného poriadku, ${ }^{9}$ ale aj na tie druhy administratívnych

napr. pre hokejistu (za predpokladu, že inkriminovaný skutok sa stal v súvislosti s výkonom jeho povolania ako profesionálneho hokejistu)v porovnaní s maximálnym desat'ročným zákazom činnosti podl’a Trestného zákona. Podrobnejšie pozri SVÁK, J. - PITEK, L. Ne bis in idem v športe? Justičná revue, roč. 61, č. 1, 2019, s. 1 - 14.

${ }^{5}$ So znalost'ou histórie možno konštatovat', že podozrenia zo zneuživania právomoci a korupcie sú evergreenom. „V sudcovskej praxi sa vytvorili pevné taxy podl’a osoby žalovaného a náročnosti prípadu, no spravidla sa nešlo pod 300000 sesterciov. Za peniaze mohol byt' oslobodený aj ten najväčši vinník a naopak odsúdeni aj tí najčestnejši muži. Tento fenomén zašiel tak d’aleko, že niekedy použivali porotní sudcovia rôzne zafarbené hlasovacie tabul'ky, aby sa úplatkár mohol presvedčit', či hlasovali podl'a jeho želania. "In GREGOR, M. Právny postih korupcie v období Rímskej republiky. 6. slovensko-české stretnutie doktorandov a postdoktorandov. Trnava : Právnická fakulta TU, 2018, s. 47.

${ }^{6}$ Oznámenie federálneho Ministerstva zahraničných vecí č. 209/1992 Z. z. Slovenský preklad článku 4 ods. 1 Protokolu č. 7 k Dohovoru v porovnaní s originálom v anglickom jazyku a vo francúzskom jazyku nepresne používa slovenské termíny „trestný čin“, „trestné konanie“, „odsúdenie“ a „rozsudok“. Tým pozmeňuje i celkový význam textu citovaného článku tohto protokolu. Podstatné v danom kontexte je predovšetkým to, že slovo „,delikt“ (vo francúzskom znení „,infraction“, v anglickom znení „offence“) zamieňa za slová „trestný čin“ (vo francúzskom znení „,infraction criminalle“, v anglickom znení „criminal offence“). Usudzovat' to možno nielen z výslovného znenia tohto článku, ale aj z jeho porovnania s predchádzajúcimi článkami Dohovoru - s článkami 2 a 3, v ktorých je použitý termín ,criminal offence“ (v anglickej verzii) a termín ,infraction criminelle“ (vo francúzskej verzii), a to v súvislosti s vymedzením práva na odvolanie $\mathrm{v}$ trestných veciach a na odškodnenie v prípade nezákonného odsúdenia.

${ }^{7}$ Pozri k tomu napr. Igor Tarasov proti Ukrajine zo 16. júna 2016, č. 44396/05, ods. 24.

${ }^{8}$ Okrem čl. 4 Protokolu č. 7 Dohovoru garantuje vnútroštátne uplatňovanie ne bis in idem čl. 14 ods. 7 Medzinárodného paktu o občianskych a politických právach (oznámenie federálneho Ministerstva zahraničných vecí č. 209/1992 Z. z.). Článok 54 Schengenského dohovoru, článok 50 Charty základných práv Európskej únie a čl. 35 ods. 1 Dohovoru o odovzdávaní trestného konania (oznámenie federálneho Ministerstva zahraničných vecí č. 551/1992 Zb.) znamenajú garanciu zákazu opätovného stíhania orgánmi viacerých štátov (resp. Schengenský dohovor a Charta tzv. úniové uplatňovanie zásady ne bis in idem).

${ }^{9}$ Zákon č. 301/2005 Z. z. Trestný poriadok v znení neskorších predpisov. 
konaní (správnych konaní), ktoré majú trestnú povahu. ${ }^{10}$ Zvýrazňujeme, že v záujme jednotnosti judikatúry súdov Správny súdny poriadok ${ }^{11}$ ustanovuje v $§ 195$ povinnost' prihliadat' a presadzovat' základné zásady trestného konania podl’a Trestného poriadku a základné zásady ukladania trestov podl’a Trestného zákona $\mathrm{v}$ rámci správneho trestania. ${ }^{12}$ Medzi tieto zásady nesporne patrí aj zásada ne bis in idem.

$\mathrm{Na}$ existenciu garancie zákazu dvojitého potrestania ne bis in idem podla čl. 4 Protokolu č. 7 Dohovoru a zodpovedajúcej rozhodovacej činnosti ESLPP je potrebné, aby boli splnené tri komponenty ${ }^{13}$ :

i) pluralita konaní (napr. trestného a trestného alebo trestného a správneho o totožnom skutku);

ii) tieto konania musia mat' trestný charakter podl'a autonómneho výkladu pojmov obsiahnutých v Dohovore - tieto prvé dva komponenty sa týkajú výkladu prvku bis;

iii) totožnost' predmetu konania, čo sa týka výkladu prvku idem.

Rozhodovacia činnost' ESL'P prvotne preferovala výklad prvku idem ako totožnosti právnej kvalifikácie ${ }^{14}$, čiže hmotnoprávny prístup ${ }^{15}$. Napokon vyvodila záver ${ }^{16}$, že prvok idem je nevyhnutné chápat' v intenciách totožnosti skutku. Výklad zameraný na totožnost' právnej kvalifikácie by zužoval rozsah práv garantovaných Dohovorom. Zachovanie totožnosti skutku znamená podl'a rozhodovacej činnosti ESL ${ }^{17}$ - zachovanie rovna-

${ }^{10}$ Pozri napr. ČENTÉŠ, J. Trestné činy daňové a zásada ne bis in idem. Právna úprava správneho trestania [elektronický zdroj]. Bratislava : Univerzita Komenského, Právnická fakulta 2015, s. 74 - 83. Ďalej ČENTÉŠ, J.: Súbeh trestného konania a daňového konania a zásada ne bis in idem. In: Justičná revueroč. 69,2017, č. 6 -7, s. $759-779$.

${ }^{11}$ Zákon č. 162/2015 Z. z. Súdny správny poriadok v znení neskorších predpisov.

${ }^{12}$ KOŠIČIAROVÁ, S. Princip ne bis in idem a správne trestanie. In Princíp spravodlivosti v trestnom a správnom súdnom konaní. Pezinok : Justičná akadémia SR, 2016, s. 156 a nasl.; MILUČKÝ, J. Správne trestanie očami nového Správneho súdneho poriadku. Princíp spravodlivosti v trestnom a správnom súdnom konaní. Pezinok : Justičná akadémia SR, 2016, s. 60 - 68. HORVAT, M. Administratívna zodpovednost' právnických osôb, Bratislava : Wolters Kluwer, 2017, s. 173.

${ }^{13}$ Napr. rozsudok vo veci Mihalache proti Rumunsku z 8. júla 2019, č. 54012/10, bod 49: „The Court observes that the wording of the first paragraph of Article 4 of Protocol No. 7 sets out the three components of the ne bis in idem principle: the two sets of proceedings must be "criminal" in nature (1); they must concern the same facts (2); and there must be duplication of the proceedings (3). It will assess each of those components in turn."

${ }^{14}$ Podl'a rozsudku Gradinger proti Rakúsku z 23. októbra 1995, č. 15963/90 bola rozhodujúcim prvkom totožnost' skutku. V prípade Oliveira proti Švajčiarsku z 30. júla 1998,č. 25711/94 súd za rozhodujúcu považoval totožnost' právnej kvalifikácie. Rozsudok vo veci Franz Fischer proti Rakúsku z 29. mája 2001, č. 37950/97 modifikuje druhý prístup tým, že stanovuje, že postačuje, aby právna kvalifikácia bola totožná v určitých podstatných prvkoch. Až následne sa súd opät’ priklonil k zásade totožnosti skutku bez ohl'adu na právnu kvalifikáciu.

${ }^{15}$ Hmotnoprávne vnímanie zásady ne bis in idem prostredníctvom inštitútu Double Jeopardy je typické aj pre common law systém. Konzekvencie tohto prístupu sa týkajú nie len súbehu viacerých konaní, ale aj súbehu trestných činov v jednom konaní. THOMAS III, G. C. Double Jeopardy. The History, the Law. New York : New York University Press, 1998, s. 32 a nasl.

${ }^{16}$ Sergey Zolotukhin proti Ruskej federácii z 10. februára 2009, č. 14939/03, bod 81.

${ }^{17} \mathrm{Z}$ novších rozhodnutí rozsudok Jóhannesson a d'alší proti Islandu z 18. mája 2017, č. 22007/11: „45. The notion of the "same offence" - the idem element of the ne bis in idem principle in Article 4 of Protocol No. 7 - is to be understood as prohibiting the prosecution or conviction of a second "offence" in so far as it arises from identical facts or facts which are substantially the same (see Sergey Zolutukhin, cited above, \$\$ 78-84)" Pozri d'alej Sergey Zolotukhin proti Ruskej federácii z 10. februára 2009, č. 14939/03, bod 81, A. a B. proti 
kých skutočností (identických faktov) alebo skutočností, ktoré sú vo svojej podstate rovnaké ako predmet $\mathrm{v}$ zbiehajúcich sa konaniach. Takáto definícia teda pripúšt’a úplne zhodné vymedzenie skutku, ako aj zachovanie podstaty skutku s určitými odlišnými skutočnost’ami, aby bola totožnost' skutku zachovaná. To je v súlade s ustálenou judikatúrou k pojmu totožnost' skutku v podmienkach slovenského vnútroštátneho práva. ${ }^{18}$ Ďalším aspektom prvku idem je totožnost' subjektu, voči ktorému sa kumulatívne vedú (viedli) konania. K porušeniu zásady ne bis in idem neprichádza, ak sa opakovane koná o totožnom skutku, avšak proti rozdielnym subjektom.

Prvok bis, teda pojem vyjadrujúci mnohost' konaní, ktoré „sa zbiehajú“ o totožnom skutku voči totožnej osobe, je potrebné vykladat' tak, že garancia ne bis in idem podl'a Dohovoru platí v prípadoch súbehu trestného konania, ako aj správneho konania, ak má konanie trestnú povahu, teda nepostačuje per se verejnoprávny charakter konania.

\section{Engelovské kritériá}

$\mathrm{Na}$ určenie trestnej povahy konania ${ }^{19}$ sa uplatňujú tri tzv. engelovské kritériá, ktoré ESL'P rozvinul v prípade Engel ${ }^{20}$ a v nasledujúcej rozhodovacej činnosti. ${ }^{21}$ Tieto kritériá majú alternatívnu povahu a pre naplnenie pôsobnosti článku 4 ods. 1 Protokolu č. 7 k Dohovoru sa vyžaduje naplnenie minimálne jedného z nich. Nedostatok trestnej povahy sankcie ${ }^{22}$ nevylučuje naplnenie prvého alebo druhého kritéria. V prípade pochybností sa však môže druhé a tretie kritérium testovat' kumulatívne. ${ }^{23}$

Prvým kritériom je právna kvalifikácia skutku vo vnútroštátnom práve, ak čin (skutok) patrí do trestného práva, tak ide o čin v zmysle Dohovoru.

Z hl'adiska druhého kritéria sa povaha deliktu z hl'adiska chráneného záujmu (všeobecný, partikulárny) skúma s ohl'adom na to, či je daný právny predpis adresova-

Nórsku z 15. novembra 2016, č. 24130/11, 29758/11, ods. 108, Šimkus proti Litve z 13. júna 2017, č. 41788/11, ods. 48 .

${ }^{18}$ Napr. uznesenie Najvyššieho súdu SR z 11. novembra 2015, sp. zn. 3 Tdo 50/2015, I. ÚS 531/2017, R 64/1973. Pozri aj REPA, O. Totožnost' skutku a skutková veta v trestnom práve. In Justičná revue, roč. 66, 2014, č. $6-7$, s. $815-821$.

${ }^{19}$ Uznesenie najvyššieho súdu z 20. apríla 2011, sp. zn. 5 Tdo 18/2011. K uvedenej problematike pozri tiež BELEŠ, A. - HAVELKOVÁ, M. Uplatňovanie zásady ne bis in idem pri disciplinárnych konaniach vo väzenstve. In Justičná revue, roč. 69, 2017, č. 2, s. 149 - 162. ČENTÉŠ, J. Uplatňovanie zásady ne bis in idem $\mathrm{v}$ rozhodnutiach slovenských súdov = Applying the principle of ne bis in idem in decisions of Slovak courts. In JELÍNEK, J. Trestní právo procesní - minulost a budoucnost. Praha : Leges, 2016, s. 129 - 142. Pozri aj Cambell a Fell v. Spojené královstvo z 28. júna 1984, Ezeh a Connors v. Spojené král'ovstvo z 9. októbra 2003 a Payet v. Francúzsko z 20. januára 2011.

${ }^{20}$ Engel a d’alší proti Holandsku z 8. júna 1976, č. 5100/71.

${ }^{21}$ Pozri LALÍK, T. Právo na spravodlivý súdny proces a zásada ne bis in idem podla Dohovoru a správne trestanie. In Justičná revue, roč. 67, č. 12, 2015, s. 1383. Na základe tejto rozhodovacej činnosti pod pôsobnost' článku 4 ods. 1 Protokolu č. 7 k Dohovoru možno podradit' aj priestupky, prípadne iné správne delikty a výnimočne aj disciplinárne delikty, ktoré majú trestnú povahu.

${ }^{22} \mathrm{Z}$ ostatného času pozri Polyakh a d’alší proti Ukrajine zo 17. októbra 2019, č. 58812/15 53217/16 59099/16, bod 154. Pozri aj KMEC, J. - KOSÁŘ, D. - KRATOCHVÍL, J. - BOBEK, M. Evropská úmluva o lidských právech. Komentář. 1. vydání. Praha : C. H. BECK, 2012, s. 578.

${ }^{23}$ Taktiež Polyakh a d'alší ..., bod 154. 
ný všetkým osobám (trestná povaha) ${ }^{24}$ alebo určitej špecifickej skupine osôb, ktoré majú osobitné postavenie, ked’že podlieha súboru osobitných napr. disciplinárnych pravidiel (sudcovia, prokurátori, vojaci, ${ }^{25}$ odsúdení ${ }^{26}$ a pod.). Pri skúmaní druhého kritéria sa tiež skúma účel sankcie, a teda či je preventívno-represívny (aspoň čiastočne) alebo reparačný. ${ }^{27}$

V rámci tretieho kritéria sa skúma stupeň prísnosti sankcie (druh a stupeň závažnosti sankcie), ktorá hrozí dotknutej osobe. Výška a charakter uloženej sankcie v konkrétnom prípade sú (spravidla) bez významu, ked’že podstatným ukazovatel’om sú výška a charakter sankcie, ktorú možno uložit’ za spáchaný delikt. ${ }^{28}$ Aplikáciou týchto kritérií možno ochranu rozšírit' aj do odvetví, ktoré nepatria do tradičných kategórií trestného práva. $^{29}$

Engelovské kritériá sú d’alej doplnené testom komplementárnosti, na ktorého základe je možné pripustit' dvojité vedenie konania a dvojitý postih totožného páchatel'a za totožný skutok, avšak prvok bis nebude naplnený vzhl’adom na určité kritériá - kritériá komplementárnosti a časovej súvislosti, ktoré ESLP podrobne definoval v rozhodnutí A. a B. proti Nórsku. ${ }^{30}$

Komplementárne konania musia byt' kombinované integrovaným spôsobom tak, aby vytvorili súvislý celok. ${ }^{31}$ To znamená, že musia spĺn̆at' nasledujúce kritériá:

i) rôzne konania sledujú doplnkové účely, a teda nielen abstraktne, ale aj konkrétne, riešia rôzne aspekty spoločensky závažného konania;

ii) dualita konania je predvídatel'ným dôsledkom toho istého skutku (idem), tak z právneho hl'adiska, ako aj v praxi;

${ }^{24}$ Kadubec proti Slovensku z 2. septembra 1998, Lauko proti Slovensku z 2. septembra 1998.Odlišná situácia je $\mathrm{v}$ prípade, ked’ predmetom disciplinárneho konania vedeného proti sudcovi je skutok právne kvalifikovaný ako priestupok (spíňa druhé engelovské kritérium). V takomto prípade disciplinárny senát zastaví disciplinárne konanie proti sudcovi podl’a $§ 124$ ods. 1 písm. b) zákona č. 385/2000 Z. z. o sudcoch a prísediacich a o zmene a doplnení niektorých zákonov v znení neskorších predpisov. Pozri aj § 9 ods. 2 zákona č. 372/1990 Zb. o priestupkoch v znení neskorších predpisov.

${ }^{25}$ Engel a d’alší proti Holandsku z 8. júna 1976.

${ }^{26}$ Ezah a Connors proti Spojenému král'ovstvu z 9. októbra 2003.

${ }^{27}$ Preventívny účel zahŕňa odradenie od páchania trestnej činnosti v budúcnosti, teda či sankcia bola uložená ako trest s ciel’om odradit' od d'alšieho páchania takýchto činov, nie s ciel'om bezprostredne zamedzit' páchatel'ovi v tom, aby vo svojej trestnej činnosti pokračoval (napr. rôzne opatrenia majúce za ciel' zabránit' vodičovi, ktorý skonzumoval alkoholické nápoje, aby mohol d'alej pokračovat'v jazde). Reparačný účel zahŕňa ekonomickú náhradu napr. v prípade úroku z omeškania.

${ }^{28}$ Podrobnejšie pozri napr. ŠAMKO, P. Daňové podvodné konania a ich dokazovanie. Bratislava : Wolters Kluwer. 2015, s. 388.

${ }^{29}$ Jussila proti Fínsku z 23. novembra 2006, č. 73053/01. ESL'P ako príklad uvádza (ods. 43): disciplinárne konanie vo väzniciach (Campbell a Fell proti Spojenému král'ovstvu z 28. júna 1984, séria A č. 80), colné právo (Salabiaku v. Francúzsko z 7. októbra 1988, séria Ač. 141-A), právo hospodárskej sútaže (Société Stenuit proti Francúzsku, 27. februára 1992, séria A č. 232-A) a sankcie uložené súdom s právomocou vo finančných záležitostiach (Guisset v. Francúzsko, č. 33933/96, ECHR 2000-IX).

${ }^{30}$ A. a B. proti Nórsku z 15. novembra 2016, č. 24130/11, 29758/11. Pre úplnost' uvádzame, že k uvedenému rozhodnutiu priložil separátne stanovisko sudca Paulo Pinto de Albuquerque, v ktorom sformuloval odlišný názor, než bol prijatý v tomto rozhodnutí.

${ }^{31}$ Tamtiež, ods. 130. 
iii) príslušné súbory konaní sú vedené takým spôsobom, aby sa v najväčšej možnej miere zabránilo duplicite pri zhromažd'ovaní, ako aj posudzovaniu dôkazov, najmä prostredníctvom primeranej interakcie medzi rôznymi príslušnými orgánmi, aby sa tak zistilo, že skutočnosti zistené v jednom konaní sa používajú aj v druhom konaní a

iv) sankcie uložené v konaniach, ktoré sú ukončené ako prvé, sa zohl'adňujú v d’alších konaniach, ktoré sú ukončené až následne, resp. ako posledné, aby sa zabránilo tomu, že dotknutá osoba bude napokon znášat' nadmerné bremeno; toto riziko sa minimalizuje, ak existuje kompenzačný mechanizmus určený na zabezpečenie toho, aby celková výška uložených sankcií bola primeraná. ${ }^{32}$

Okrem kritéria komplementárnosti sa vyžaduje aj kumulatívne splnenie kritéria časovej súvislosti, ktorá musí byt' dostatočne úzka, aby chránila jednotlivca pred neistotou, priet’ahmi a predlžovaním konania aj v prípadoch, ked' vnútroštátny systém obsahuje integrovaný systém oddel'ujúci správne a trestné zložky. ${ }^{33}$

Z uvedeného vyplýva, že tak ako engelovské kritériá rozširujú ochranu, kritériá komplementárnosti a časovej súvislosti znamenajú zúženie širokého výkladu engelovských kritérií, a teda aj ochrany.

\section{Súbeh disciplinárneho konania a trestného konania z pohl'adu rozhodovacej činnosti ESL'P}

Vzhl'adom na rozmanitost' správnych konaní nie je možné všeobecne ustanovit', že práva priznané v trestnom konaní sa musia uplatňovat' pri rozhodovaní o akomkolvek správnom delikte. To platí najmä o disciplinárnych deliktoch, ktorých trestnú povahu nemožno konštatovat' na základe druhého engelovského kritéria (napr. nie sú priestupkami). Disciplinárna zodpovednost' pri týchto disciplinárnych deliktoch totiž môže vzniknút' len vnútri určitej organizačnej štruktúry, teda nemá externé účinky. ${ }^{34}$ A contrario, účinky zodpovednosti pri disciplinárnych deliktoch sú interné, ked’že sa vyvodzujú voči špecifickej skupine osôb, ktoré majú právny vzt’ah k organizačnej štruktúre určitých orgánov alebo inštitúcií (napr. na základe menovania, vol'by, pracovnej zmluvy) ${ }^{35}$ - teda disciplinárne delikty sledujú partikulárne záujmy týchto orgánov alebo inštitúcií (napr. súdneho systému). Do úvahy tak prichádza určenie trestnej povahy disciplinárneho deliktu len na základe tretieho engelovského kritéria. Sankcie sa pri jednotlivých typoch disciplinárnych deliktov odlišujú, preto pri každom type je potrebné skúmat' trestnú povahu disciplinárneho deliktu osobitne. ${ }^{36}$

${ }^{32}$ Tamtiež, ods. 132.

${ }^{33}$ LACIAK, O. Právo nebyt' stíhaný dvakrát za ten istý skutok (ne bis in idem) = Right not to be tried for the same offence (doublejeopardy). In JELÍNEK, J. a kol. Ochrana zákládních práv a svobod v trestnim rízení. Praha : Leges, 2020, s. 126. Pozri aj Jóhannesson a d’alší proti Islandu z 18. mája 2017, č. 22007/11 a Bjarni Ármansson proti Islandu zo 16. apríla 2019, č. 72098/14.

${ }^{34}$ MACHAJOVÁ, J. - SOBIHARD, J. Iné správne delikty. In MACHAJOVÁ, J. a kol. V̌̌eobecné správne právo. 5. aktualizované vydanie. Bratislava : Eurokódex, 2010, s. 289.

${ }^{35}$ CEPEK, B. Správne disciplinárne delikty. In VRABKO, M. a kol. Správne právo hmotné. Všeobecná čast'. Bratislava: C. H. Beck, 2012, s. $306-307$.

${ }^{36}$ Demel proti Rakúsku zo 16. apríla 1998, č. 30993/96. Trestnú povahu je možné disciplinárnemu konaniu voči obvineným a odsúdeným priznat', ak následkom uloženej sankcie v takom disciplinárnom konaní je 
ESL'P vo svojej rozhodovacej činnosti doposial' nedospel v žiadnom svojom rozhodnutí k právnemu názoru, že disciplinárne konanie sudcu by bolo možné považovat' aj za trestné konanie. Disciplinárne konanie, ktoré vedie k prepusteniu sudcu alebo má iné závažné dôsledky, ESL'P považuje za civilné konanie, na ktoré sa vzt’ahuje civilná vetva čl. 6 Dohovoru. ${ }^{37}$ Podl'a ESL'P nie je disciplinárne obvinenie sudcu považované za trestné obvinenie podl'a čl. 6 Dohovoru, resp. disciplinárny delikt za trestný čin podl'a čl. 4 Protokolu č. 7 k Dohovoru. Známymi rozhodnutiami už z 90. rokov ${ }^{38}$, v ktorých disciplinárnym konaniam voči sudcom nebola priznaná trestná povaha, sú Kremzow proti Rakúsku $^{39}$ a Demel proti Rakúsku. ${ }^{40}$

V prípade Kremzow bol sudca odsúdený za závažnú trestnú činnost'. V disciplinárnom konaní mu následne boli odňaté požitky súvisiace s postavením penzionovaného emeritného sudcu. Komisia konštatovala, že úloha disciplinárneho súdu sa v podstate obmedzovala na preskúmanie otázky, či v prípade, ak je st’ažovatel’om sudca vo výslužbe, je možné závažný trestný čin, za ktorý bol uznaný vinným, kvalifikovat' zároveň aj ako disciplinárne previnenie. Sankcie uložené v disciplinárnom konaní boli podl’a názoru Komisie typické sankcie, ktoré v týchto prípadoch stanovujú disciplinárne predpisy štátnych úradníkov mnohých zmluvných štátov: odňatie práv spojených s profesionálnym postavením štátneho zamestnanca vrátane straty dôchodkových práv. Komisia fakticky testovala tretie engelovské kritérium, hoci to neuviedla explicitne. Výsledkom bolo, že disciplinárne konanie voči sudcovi nemá trestný charakter, a preto k porušeniu zásady ne bis in idem neprišlo.

Posúdenie disciplinárneho konania voči sudcovi v prípade Demel bolo podobné. Sankcia, ktorá mohla byt' st’ažovatel’ovi v disciplinárnom konaní uložená, mohla spočívat' v pokarhaní, sudcovskom penzionovaní so zníženým dôchodkom alebo dokonca až v odňatí funkcie sudcu. Toto je potrebné vziat' do úvahy, ked’že na určenie závažnosti sankcie podl'a tretieho engelovského kritéria je potrebné posúdit', akú sankciu bolo možné potenciálne uložit' (nie aká bola uložená). ${ }^{41}$ Komisia v prípade Demel odkázala na prípad Kremzow a pripomenula, že odňatie práv spojených s profesionálnym postavením štátneho zamestnanca vrátane straty nároku na dôchodok sú typickou sankciou

predíženie trvania odňatia slobody alebo vylúčenie možnosti skrátenia trvania odňatia slobody, napr. odsúdený nebude podmienečne prepustený. Odňatie slobody bolo za závažnú sankciu s trestným charakterom považované aj v samotnom prípade Engel a d'alší. Bližšie pozri BELEŠ, A. - HAVELKOVÁ, M. Uplatňovanie zásady ne bis in idem pri disciplinárnych konaniach vo väzenstve. In Justičná revue, roč. 69, 2017, č. 2, s. 149 - 162, BELEŠ, A. Uplatňovanie zásady ne bis in idem v disciplinárnom konaní vo výkone väzby a výkone trestukazuistický pohl'ad. In Policajná teória a prax, roč. 25, č. 3, 2017, s. 81 - 95.

${ }^{37}$ Olujić proti Chorvátsku z 5. februára 2009, č. 22330/05, § $32-44$, v ktorom išlo o odvolanie z funkcie sudcu. Pozri aj pozri Jakšovski a Trifunovski proti Macedónsku zo 7. januára 2016, č. 56381/09 a 58738/09, § 32; Gerovska Popčevska proti Macedónsku zo 7. januára 2016, č. 48783/07, § 38) In Ústavný súd Českej republiky I. ÚS 2617/15.

${ }^{38}$ Pozri tiež Príručka judikatúry ESL'P. Právo nebyt’ opakovane súdený alebo trestaný (preklad B. Babáková) In Bulletin oddelenia dokumentácie, analytiky a komparatistiky Kancelárie Najvyššieho súdu Slovenskej republiky, s. 47 a nasl.

${ }^{39}$ Rozhodnutie Komisie vo veci Kremzow proti Rakúsku zo 7. novembra 1990, č. 16417/90.

${ }^{40}$ Rozhodnutie Komisie vo veci Demel proti Rakúsku zo 16. apríla 1998, č. 30993/96.

${ }^{41}$ Napr. Sergey Zolotukhin proti Ruskej federácii z 10. februára 2009, č. 14939/03, ods. 56. 
disciplinárneho práva. Sankcie, o ktoré ide v prejednávanej veci (Demel), mali teda čisto disciplinárnu povahu, a teda záruka ne bis in idem sa neuplatnila.

V ostatnom období sa ESL'P zaoberal problematikou disciplinárnych konaní v prípade Ramos Nunes de Carvalho e Sá proti Portugalsku², a to v súvislosti s čl. 6 Dohovoru. ESL'P uviedol, že ustanovenia o disciplinárnej zodpovednosti sudcov nie sú zamerané na verejnost' všeobecne - ich účelom je chránit' čest' a povest' povolania a udržiavat' dôveru verejnosti v súdnictvo. Druhé kritérium teda nie je splnené. V súvislosti s tretím kritériom ESL'P konštatoval, že všetky sankcie, ktoré sudcovi mohli byt' uložené, majú čisto disciplinárnu povahu. Aj ked' výška peňažnej sankcie môže byt' značná, a preto má represívny charakter, prísnost' sankcie per se nezakladá trestnú povahu disciplinárneho deliktu. ${ }^{43}$

Podobne ESL'P odmietol trestnú povahu disciplinárnych konaní voči sudcom v prípadoch Kamenos proti Cypru ${ }^{44}$ (sankcia: zbavenie funkcie sudcu), Oleksandr Volkov proti Ukrajine $^{45}$ (taktiež, pričom súd pripomenul, že zbavenie funkcie alebo prepustenie je typickou disciplinárnou sankciou, pričom zdôraznil, že st'ažovatel'ove odvolanie z postu sudcu mu nebránilo vo výkone inej právnickej profesie /§ 93/), resp. Sturua proti Gruzínsku (zbavenie funkcie) $)^{46}$, ako aj Di Giovanni proti Taliansku. ${ }^{47}$

\section{Disciplinárne konanie proti sudcovi}

Všeobecne možno uviest', že disciplinárna zodpovednost' je správnoprávna zodpovednost', ktorej existencia je výrazom potreby zabezpečit' dodržiavanie predpísaných pravidiel $\mathrm{v}$ relatívne ucelených a stabilizovaných organizačných štruktúrach, pričom disciplinárneho deliktu sa môže dopustit' konkrétna osoba, ktorý má určitý (právny) vzt’ah $\mathrm{k}$ danej organizačnej sústave. ${ }^{48}$ Konkrétna disciplinárna zodpovednost' sudcu sa uplatňuje vo vzt’ahu k organizačnej štruktúre súdu, s osobitnými právami a povinnost'ami vyplývajúcimi z tohto vzt’ahu.

Základným zmyslom disciplinárneho konania je najmä ochrana integrity sudcovského stavu, nezávislosti a nestrannosti sudcov a súdnej moci a dôvery verejnosti v nezávislé, nestranné a spravodlivé rozhodovanie sudcov. Funkcia sudcu predstavuje v profesijnom i mimoprofesijnom pôsobení pozíciu ústavného činitel'a, u ktorého je nevyhnutné vyžadovat' čo najprísnejšie plnenie povinností, ktoré sú s výkonom tejto funkcie spojené. ${ }^{49}$ Disciplinárne konanie teda primárne sleduje iný účel ako trestné konanie (§ 1 Trest-

\footnotetext{
${ }^{42}$ Ramos Nunes de Carvalho e Sá proti Portugalsku zo 6. novembra 2018, č. 55391/13, 57728/13, $74041 / 13$.

${ }^{43}$ Primerane ods. 125 a 126 predmetného rozhodnutia.

${ }^{44}$ Kamenos proti Cypru z 31. októbra 2017, č. 147/07, ods. 50 až 53.

${ }^{45}$ Oleksandr Volkov proti Ukrajine z 9. januára 2013, č. 21722/11, ods. 93 až 95.

${ }^{46}$ Sturua proti Gruzínsku z 28. marca 2017, 45729/05, ods. 28.

${ }^{47}$ Di Giovanni proti Taliansku z 9. júla 2013, č. 51160/06, ods. 35.

${ }^{48}$ Primerane pozri KEISLER, I. Disciplinárni odpovědnost osob ve služebním poměru. Časopis pro právní vědu a praxi, roč. XXIV, 2016, č. 4, s. 626.

${ }^{49}$ Primerane pozri rozhodnutie Najvyššieho správneho súdu Českej republiky z 18. februára 2015, sp. zn. 13 Kss 6/2014-38.
} 
ného poriadku) - hoci uplatňujú podobné procesné inštitúty ${ }^{50}$ - a tento fakt potvrdzuje možnost' súbehu disciplinárneho a trestného konania, ako to vyplýva z rozhodovacej činnosti ESL'P.

Zákon o sudcoch a prísediacich ${ }^{51}$ ustanovuje disciplinárnu zodpovednost' sudcu za disciplinárne previnenie, ${ }^{52}$ pričom vymenúva disciplinárne opatrenia (sankcie), ktoré možno uložit' za disciplinárne previnenie. ${ }^{53}$

Podl'a $§ 117$ zákona o sudcoch sa za disciplinárne previnenia uložia disciplinárne opatrenia, ktorými môžu byt' (ods. 1) : a) napomenutie, b) zníženie funkčného platu až o $30 \%$ na obdobie najviac troch mesiacov (pri opätovnom disciplinárnom previnení, ktorého sa sudca dopustil $\mathrm{v}$ čase pred zahladením disciplinárneho postihu, na obdobie najviac šiestich mesiacov), c) vydanie a zverejnenie rozhodnutia o tom, že dotknutý sudca v príslušnom roku nepreukázal zákonom ustanoveným spôsobom zdroj svojich majetkových prírastkov.

Za závažné disciplinárne previnenie sa podl’a $§ 117$ ods. 3 zákona o sudcoch a prísediacich uloží: a) preloženie sudcu na súd nižšieho stupňa, b) zníženie funkčného platu o $50 \%$ až $70 \%$ na obdobie troch mesiacov až jedného roka, c) vydanie a zverejnenie rozhodnutia o tom, že dotknutý sudca v príslušnom roku nepreukázal zákonom ustanoveným spôsobom zdroj svojich majetkových prírastkov, čím mohol narušit' vážnost' a dôstojnost' funkcie sudcu alebo ohrozit’ dôveru v nezávislé, nestranné a spravodlivé rozhodovanie súdov; príp. až odvolanie z funkcie sudcu, ak ide o disciplinárne previnenie nezlučitel'né s funkciou sudcu (§ 117 ods. 5 zákona o sudcoch a prísediacich).

Druhy disciplinárnych opatrení (sankcií), ich závažnost' a citel’nost' v disciplinárnom konaní proti sudcovi sú zjavne odlišné ako tresty (sankcie), ich závažnost' a citel'nost' v trestnom konaní. Disciplinárne opatrenia, ktoré možno uložit' sudcovi, sú typickými sankciami disciplinárnych predpisov, ako bolo uvedené v prípade Kremzow. Hrozba odvolania sudcu z funkcie ako najtvrdšia sankcia v disciplinárnom konaní nedosahuje závažnost' hrozby uloženia trestu odňatia slobody, príp. d’alších trestov v trestnom konaní. A fortiori, túto závažnost' nedosahujú miernejšie sankcie, ktoré je možné uložit' v disciplinárnom konaní. Tretie engelovské kritérium nie je splnené.

Z týchto dôvodov nič nebráni, aby po uložení disciplinárneho opatrenia proti sudcovi sa voči nemu následne viedlo trestné konanie (stíhanie), prípadne, aby mu bol uložený trest v trestnom konaní - za totožný skutok. Možno zvýraznit', že opačná situácie nie je možná, pretože podla $§ 124$ ods. 1 písm. e) zákona o sudcoch a prísediacich disciplinár-

\footnotetext{
${ }^{50}$ Napr. LINDGEN, E. Handbuch des Disziplinarrechts für Beamte und Richter in Bund und Ländern. Berlin : De Gruyter, 1968, s. 1.

${ }^{51}$ Zákon č. 385/2000 Z. z. o sudcoch a prísediacich a o zmene a doplnení niektorých zákonov v znení neskorších predpisov.

${ }^{52}$ Ust. § 116 zákona o sudcoch a prísediacich.

${ }^{53}$ Podl’a súdnej praxe disciplinárny senát pri ukladaní disciplinárneho opatrenia podl’a $\S 117$ zákona o sudcoch a prísediacich prihliadne na rozsah a povahu porušenej povinnosti, spôsob konania sudcu, následok a mieru zavinenia sudcu. Ďalej zohl'adní aj predchádzajúcu rozhodovaciu činnost' sudcu a zložitost' prejednávanej veci - primerane pozri rozhodnutie Najvyššieho súdu Slovenskej republiky - disciplinárneho senátu z 19. septembra 2016, sp. zn. 4 Ds 2/2016.
} 
ny senát bez ústneho pojednávania konanie zastaví, ak o skutku, pre ktorý sa disciplinárne konanie vedie, sa právoplatne rozhodlo v trestnom konaní. Zákon o sudcoch a prísediacich z pohl'adu svojich dôsledkov nerozlišuje dôvod, pre ktorý napr. bolo trestné stíhanie zastavené, ani štádium trestného konania, v ktorom $\mathrm{k}$ zastaveniu trestného stíhania došlo. ${ }^{54}$

Zákon o sudcoch a prísediacich ustanovuje postup $\mathrm{v}$ prípade, ak sa disciplinárny senát domnieva, že skutočnosti, ktoré sa sudcovi kladú za vinu, majú znaky trestného činu. V takomto prípade disciplinárne konanie preruší a vec postúpi príslušnému orgánu činnému v trestnom konaní. Rovnako disciplinárny senát preruší disciplinárne konanie aj vtedy, ak sa dozvie, že pre skutok, pre ktorý sa disciplinárne konanie začalo, sa proti sudcovi vedie trestné konanie. ${ }^{55}$

Správne aplikovanie zákona má význam tiež v prípade, ked’ zákonné znaky trestného činu sú obdobné, ako zákonné znaky disciplinárneho previnenia. Od 1. januára $2021 \mathrm{sa}$ stal súčast’ou Trestného zákona trestný čin ohýbania práva podl’a § 326a Trestného zákona, ktorý kriminalizuje aj konanie sudcu (okrem prísediaceho sudcu a rozhodcu rozhodcovského súdu), ktorý pri rozhodovaní svojvol’ne uplatní právo a iného tým poškodí alebo zvýhodní. Skutková podstata trestného činu ohýbania práva je sčasti obdobná ako závažné disciplinárne previnenie podl’a $§ 116$ ods. 2 písm. e) zákona o sudcoch a prísediacich, ktoré umožňuje vyvodenie disciplinárnej zodpovednosti za svojvol'né rozhodnutie sudcu, ktoré je v rozpore s právom, ak týmto rozhodnutím sudca spôsobí značnú škodu alebo iný obzvlášt' závažný následok. Možno poukázat' na okolnost', že skutková podstata disciplinárneho previnenia je z hl'adiska následku prísnejšia (spôsobenie značnej škody alebo iného obzvlášt' závažného následku) ako skutková podstata trestného činu ohýbania práva. $\mathrm{Z}$ tohto dôvodu bude nutné $\mathrm{v}$ prípade svojvol'ného rozhodnutia sudcu a splnenia d'alších zákonných podmienok, zo strany orgánov verejnej moci vel'mi pozorne skúmat' podmienky na vyvodenie trestnoprávnej zodpovednosti sudcu.

Zohl'adnenie disciplinárneho opatrenia (sankcie) uloženej sudcovi v disciplinárnom konaní môže byt' relevantné v prípade, ak sa proti nemu následne vedie trestné konanie (stíhanie) za totožný skutok, a to najmä v prípade splnenia fakultatívnych dôvodov zastavenia trestného stíhania.

\section{Právna úprava v Trestnom poriadku}

Vzhl’adom na zameranie tohto článku sa sústredíme na prezentovanie nášho názoru na aplikovanie relevantných ustanovení Trestného poriadku vo vzt’ahu k fakultatívnym dôvodom zastavenia trestného stíhania sudcu po tom, čo mu bolo uložené disciplinárne opatrenie za totožný skutok.

${ }^{54}$ Rozhodnutie Najvyššieho súdu Slovenskej republiky - disciplinárneho senátu z 27. januára 2014, sp. zn. 1 Ds 8/2014. Ďalej pozri rozhodnutie Najvyššieho súdu Slovenskej republiky - disciplinárneho senátu z 21. novembra 2011, sp. zn. 1Ds $1 / 2011$.

${ }^{55}$ Ust. § 125 ods. 1 a ods. 2 zákona o sudcoch a prísediacich. Prerušenie disciplinárneho konania trvá do právoplatnosti rozhodnutia v trestnom konaní. Ak nie sú splnené podmienky na pokračovanie v disciplinárnom konaní alebo na konanie v osobitných prípadoch, disciplinárny senát disciplinárne konanie zastaví. 
Pre právne posúdenie tejto situácie je relevantná právna úprava $\mathrm{v}$ Trestnom poriadku. ${ }^{56}$ Podl'a $§ 215$ ods. 2 písm. b) Trestného poriadku prokurátor môže zastavit’ trestné stíhanie, ak o skutku obvineného bolo už právoplatne rozhodnuté disciplinárne iným orgánom (...) a toto rozhodnutie možno považovat' za dostačujúce. ${ }^{57}$ Obdobne $\S 241$ ods. 1 písm. e) Trestného poriadku umožňuje samosudcovi a § 244 ods. 1 písm. d) Trestného poriadku senátu za rovnakých podmienok ako $§ 215$ ods. 2 písm. b) Trestného poriadku zastavit' trestné stíhanie. ${ }^{58}$

Uvedená právna úprava akceptuje vedenie trestného konania za skutok, za ktorý už bolo vo vzt’ahu k jednotlivcovi právoplatne rozhodnuté v disciplinárnom konaní. V takomto prípade Trestný poriadok fakultatívne umožňuje prokurátorovi v prípravnom konaní, v súdnom konaní samosudcovi, resp. senátu, aby rozhodli o zastavení trestného stíhania.

Rozhodujúcou podmienkou zastavenia trestného stíhania $v$ tomto prípade je, či toto rozhodnutie možno považovat’ za dostačujúce. Splnenie tejto podmienky vyžaduje, aby prokurátor alebo súd vel'mi precízne vyhodnotili konkrétne okolnosti prípadu a osobu obvineného.

Z hl'adiska naplnenia fakultatívnych dôvodov zastavenia trestného stíhania sudcu sme sa nestretli s takýmto právoplatným uznesením v Slovenskej republike (čo však nevylučuje, že takéto rozhodnutie bolo vydané). Z tohto dôvodu - z hl'adiska komparatívnej metódy výkladu práva - priblížime fakultatívne dôvody zastavenia trestného stíhania vedeného proti sudkyni v Českej republike. Podstata skutku spočívala v tom, že obvinená ako zákonná sudkyňa okresného súdu nezabezpečila, aby o d’alšom trvaní väzby obžalovaného bolo rozhodnuté v zákonnej lehote, ktorá uplynula dňa 18. mája 2016, a následne dňa 19. mája 2016 vyhotovila uznesenie o ponechaní obžalovaného vo väzbe, ktoré označila dátumom 18. mája 2016 a dala pokyn k jeho odoslaniu namiesto toho, aby obžalovaného z väzby bezodkladne prepustila, pričom obžalovaný bol nezákonne vo väzbe do 26. mája 2016. Za uvedený skutok kvalifikovaný ako kárne previnenie bola sudkyňa rozhodnutím Najvyššieho správneho súdu Českej republiky uznaná vinnou a bolo jej uložené kárne opatrenie - zníženie platu o $25 \%$ na dobu jedného roka. ${ }^{59}$

Za totožný skutok bolo následne proti sudkyni vedené trestné stíhanie, ktoré bolo uznesením okresného súdu v spojení s uznesením krajského súdu zastavené z dôvodu

${ }^{56}$ Primárnym predpokladom na naplnenie fakultatívnych dôvodov zastavenia trestného stíhania podla $\S 215$ ods. 2 písm. b) Trestného poriadku je predchádzajúci záver o tom, že sa skutok stal, vykazuje znaky skutkovej podstaty trestného činu, dôvodnost' obvinenia, neexistencia dôvodov pre zastavenie trestného stíhania podl'a $\S 215$ ods. 1 Trestného poriadku a do úvahy neprichádza taká kvalifikácia skutku, ktorá by aplikáciu fakultatívnych dôvodov zastavenia trestného stíhania vylučovala (primerane pozri uznesenie Najvyššieho súdu Slovenskej republiky zo 4. marca 1993, sp. zn. 8 Tz 4/93) a uplatnenie všetkých dôsledkov trestnej represie nie je potrebné s ohl'adom na predchádzajúci postih obvineného inými právnymi prostriedkami pre totožný skutok.

${ }^{57}$ Pre úplnost' uvádzame, že ustanovenie $\S 197$ ods. 2 Trestného poriadku umožňuje, aby prokurátor alebo policajt rozhodli pri zohl'adnení sankcie (disciplinárneho opatrenia) za ten istý skutok aj v postupe pred začatím trestného stíhania, a to odložením (§ 197 ods. 2 vzhl'adom na okolnosti uvedené v $§ 215$ ods. 2 Trestného poriadku).

${ }^{58}$ Obdobne pozri aj $\S 281$ ods. 2 a $§ 290$ ods. 1 Trestného poriadku.

${ }^{59}$ Rozhodnutie Najvyššieho správneho súdu Českej republiky zo 7. júna 2017, sp. zn. 13 Kss 3/2017-77. 
naplnenia fakultatívnych dôvodov. Proti tomuto uzneseniu podal najvyšší štátny zástupca Českej republiky dovolanie, o ktorom rozhodol Najvyšší súd Českej republiky. ${ }^{60}$ Vo svojom rozhodnutí Najvyšší súd Českej republiky všeobecne uviedol, že faktická neúčelnost' d'alšieho trestného stíhania z dôvodu postačujúceho rozhodnutia o skutku iným orgánom musí mat' podklad v skutkovom zistení, že sú dané okolnosti, ktorými dochádza k naplneniu zákonných predpokladov aplikácie $\S 172$ ods. 2 písm. b) Trestného poriadku [v slovenskom Trestnom poriadku ustanovenie $\S 215$ ods. 2 písm. b)]. Týmito sú predchádzajúce rozhodnutie o skutku obvineného iným orgánom, ktoré musí byt' vyhodnotené ako dostačujúce. ${ }^{61}$

V posudzovanom prípade záver o faktickej neúčelnosti d’alšieho trestného stíhania z dôvodu uloženého kárneho, t. z. disciplinárneho opatrenia obvinenej sudkyni podl'a názoru Najvyššieho súdu Českej republiky mal podklad v zistení, že najmä z hl’adiska povahy a závažnosti konania, pomerov obvinenej, možnosti jej nápravy, ochrany spoločnosti a d'alších kritérií ustanovených v $§ 39$ ods. 2, 3 Trestného zákonníka je uložené kárne opatrenie dostačujúce. Najvyšší súd Českej republiky prihliadol aj na hodnotenie predsedu okresného súdu, ktorý uviedol, že kárne stíhanie a trestné stíhanie obvinenej nielen pre ňu, ale aj pre mladších kolegov bolo významným poučením, a čo do prevencie splnilo svoj účel.

S prihliadnutím na uvedené rozhodnutie a jeho závery možno zaujat' právny názor, že aplikovanie fakultatívnych dôvodov zastavenia trestného stíhania po uložení predchádzajúceho disciplinárneho opatrenia (sankcie) sudcovi za totožný skutok by malo byt' výnimočné.

Na odlíšenie jednotlivých protiprávnych konaní sudcov možno uviest' niekol'ko fiktívnych prípadov vo vzt'ahu k vedeniu disciplinárneho konania, resp. trestného konania (stíhania).

V prípade, ak by napr. počas hlavného pojednávania bol vyhotovený zvukový záznam, ktorý by obsahoval výpovede procesných strán (obžalovaného, svedkov, znalcov a pod.) a následne by sudca upravil písomný prepis zvukového záznamu výpovedí $\mathrm{z}$ hlavného pojednávania $\mathrm{v}$ rozpore so skutočnou výpoved’ou osôb zaznamenaných na zvukovom zázname, bez toho, aby mal úmysel poškodit' procesné strany, pripadalo by do úvahy najmä disciplinárne konanie.

Odlišná situácia by nastala v prípade, ak by sudca písomný prepis zvukového záznamu z hlavného pojednávania upravil tak, aby prišlo k výrazným posunom obsahovej zmeny jednotlivých výpovedí, v rozpore so skutočne zisteným skutkovým stavom, $\mathrm{v}$ úmysle dosiahnut' ich odsúdenie. V takomto prípade by bolo zjavné, že voči sudcovi možno vyvodit' iba trestnoprávnu zodpovednost'.

Pri aplikovaní zastavenia trestného stíhania z fakultatívnych dôvodov je potrebné dôsledne vyhodnotit' $\mathrm{v}$ konkrétnom prípade závažnost' protiprávneho konania sudcu $\mathrm{v}$ porovnaní $\mathrm{s}$ bežne sa vyskytujúcimi trestnými činmi danej skutkovej podstaty, ktorých závažnost' je vyjadrená konkrétnou trestnou sadzbou trestu odňatia slobody. V rámci

\footnotetext{
${ }^{60}$ Uznesenie Najvyššieho súdu Českej republiky z 18. decembra 2019, sp. zn. 8 Tdo 1283/2019.

${ }^{61}$ R 14/1971-II, R 23/1976.
} 
tohto vyhodnotenia by sa malo zohl'adnit' aj to, či povaha a závažnost' konkrétneho skutku spolu s osobou sudcu vedú k presvedčivému a odôvodnenému záveru, že na d’alšom trestnom stíhaní nie je daný verejný záujem. ${ }^{62}$

Rozhodne by sa nemal tento inštitút aplikovat' v prípade, ked' je preukázané, že protiprávne konanie sudcu bolo motivované zištným úmyslom, prípadne ked' sú zrejmé korupčné vplyvy, alebo ak sa konania dopustil s úmyslom poškodit’ tretiu osobu. Rovnako by sa nemal aplikovat' $\mathrm{v}$ prípade svojvol'ného rozhodovania sudcu alebo protiprávneho konania sudcu, ktoré možno kvalifikovat' ako zločin. Dôležité je tiež vyhodnotit' predchádzajúcu právnu a sudcovskú kariéru sudcu, najmä to, či ide o ojedinelý exces, alebo či sa už v minulosti vyskytlo iné pochybenie.

Je potrebné uvedomit' si, že takýmito konaniami sudca narúša dôstojnost' sudcovskej funkcie a ohrozuje dôveru verejnosti v nezávislé, nestranné, odborné a spravodlivé rozhodovanie súdov. Ústavná pozícia súdnej moci je založená na tejto dôvere. Bez dôvery stráca súdna moc legitimitu. ${ }^{63}$ Je zjavné, že vnímanie súdnej moci ako dôveryhodnej môže byt' narušené, ak je vedené proti určitému sudcovi disciplinárne konanie či trestné konanie.

\section{Záver}

Zákonné vyvodenie disciplinárnej zodpovednosti voči sudcovi v podmienkach Slovenskej republiky môže predstavovat' nevyhnutný prvok okamžitej reakcie na porušovanie jeho zákonných povinností. Niektoré protiprávne činy (skutky) sudcu môžu predstavovat' výlučne porušenie povinností vyplývajúcich z ich stavovských predpisov [napr. správanie, ktoré vzbudzuje oprávnené pochybnosti o nezávislosti a nestrannosti sudcu podl'a $§ 116$ ods. 1 písm. b) zákona o sudcoch a prísediacich]. Niektoré protiprávne činy (skutky) okrem naplnenia skutkovej podstaty disciplinárneho previnenia môžu naplnit’ aj skutkovú podstatu trestného činu, následkom čoho vzniká potreba adekvátnej trestnoprávnej reakcie.

Avšak potreba okamžitej reakcie v podobe uloženia disciplinárneho opatrenia tým nie je vylúčená. Ak k takej reakcii neprichádza, sudcovi môže byt' umožnené opakovanie porušovania povinností, resp. páchanie protiprávneho konania. K tomu pristupuje aspekt absencie generálnej prevencie: sudcovi - porušitel'ovi práva - je de facto demonštrované, že následkom protiprávneho konania nie je okamžitá reakcia subjektu oprávneného vykonat' disciplinárne konanie, ale následkom je výlučne relatívne zdíhavé trestné konanie (stíhanie). Významným aspektom je aj oslabovanie presvedčenia verejnosti vo fungovanie právneho štátu a realizácie spravodlivosti, ak voči porušeniam povinností sudcu nie je postupované dostatočne rýchlo a adekvátne vážnosti funkcie sudcu. ${ }^{64}$ Naopak,

${ }^{62}$ Primerane pozri uznesenie Najvyššieho súdu Českej republiky z 18. decembra 2019, sp. zn. 8 Tdo $1283 / 2019$.

${ }^{63}$ Primerane pozri uznesenie Najvyššieho správneho súdu Českej republiky z 30. septembra 2020, sp. zn.13 Kss 5/2020.

${ }^{64}$ Včasný a adekvátny postih previnení sudcov je dôležitým aspektom aj z historickoprávneho pohl'adu. Už Zákon XII. tabúl' v starom Ríme umožňoval trestne stíhat' nepoctivého alebo inak zaujatého sudcu, ktorému v prípade dokázania viny hrozilo uloženie trestu smrti. Zároveň to bol jeden z mála dôvodov, ktorý umožňoval vznesenie odvolania v rímskom procese. K tomu pozri: SKŘEJPEK, M. Litem suam facere. In Právněhistorické 
disciplinárna zodpovednost' má chránit' čest' a povest' povolania sudcu, ako ESLPP pripomenul v prípade Ramos Nunes de Carvalho e Sá proti Portugalsku. Trestná zodpovednost' by mala byt' vylúčená len v situáciách, ked' uplatnením iného druhu zodpovednosti je možné dosiahnut' naplnenie všetkých funkcií trestného práva. ${ }^{65}$

Súbeh disciplinárneho sankcionovania voči sudcovi na jednej strane a následné trestnoprávne sankcionovanie na strane druhej za totožný skutok má tak svoj praktický zmysel a nie je dôvod ho potláčat' $v$ obave z vytvorenia prekážky veci rozhodnutej, ked'že disciplinárne konanie voči sudcom nemá trestnú povahu.

Zároveň možno zvýraznit', že Trestný poriadok umožňuje zohl'adnit' disciplinárne opatrenie (sankciu) uloženú sudcovi v disciplinárnom konaní v prípade, ak sa proti nemu následne vedie trestné konanie (stíhanie) za totožný skutok, a to najmä v prípade splnenia fakultatívnych dôvodov zastavenia trestného stíhania.

\section{Literatúra}

BELEŠ, A., HAVELKOVÁ, M. Uplatňovanie zásady ne bis in idem pri disciplinárnych konaniach vo väzenstve. Justičná revue, roč. 69,2017 , č. 2, s. $149-162$

BELEŠ, A. Uplatňovanie zásady ne bis in idem v disciplinárnom konaní vo výkone väzby a výkone trestu kazuistický pohl’ad. Policajná teória a prax, roč. 25, 2017, č. 3, s. $81-95$

BELEŠ, A. Uplatňovanie zásady ne bis in idem pri disciplinárnych konaniach príslušníkov ozbrojených bezpečnostných zborov. Zborník z medzinárodnej vedeckej konferencie doktorandov a mladých vedeckých pracovníkov Míl'niky práva v stredoeurópskom priestore 2017, organizovanej Univerzitou Komenského v Bratislave, Právnickou fakultou, v dňoch 30. 3. - 1. 4. 2017, s. $684-691$

BERNARD, D. Ne bis in idem - Protector of Defendants' Rights or Jurisdictional Pointsman. Journal of International Criminal Justice, roč., 2011, č. 9, č. 4, s. 865

ČENTÉŠ, J. Súbeh trestného konania a daňového konania a zásada ne bis idem. Justičná revue, roč. 69, 2017, č. $6-7$, s. $757-779$

ČENTÉŠ, J. Trestné činy daňové a zásada ne bis in idem. Právna úprava správneho trestania [elektronický zdroj]. Bratislava : Univerzita Komenského, Právnická fakulta 2015, s. 74 - 83

ČENTÉŠ, J. Uplatňovanie zásady ne bis in idem v rozhodnutiach slovenských súdov = Applyingthe principle of ne bis in idem in decisions of Slovak court. In JELÍNEK, J. Trestní právo procesní - minulost a budoucnost; Praha : Leges, 2016, s. 129 - 142

ČENTÉŠ, J. Vybrané aspekty zásady ne bis in idem v trestnom konaní. In Princíp spravodlivosti v trestnom a správnom súdnom konaní. Pezinok : Justičná akadémia SR, 2016, s. 156 - 168

FUCHS, H. RATZ, E. Wiener Kommentar zur StPO. Dostupný na rdb.at cit. 11. 11. 2017

GREGOR, M. Inštitút odvolania vo formulovom a v kogničnom procese. In Pôžička či úžera? Nútený výkon rozhodnutia - rímskoprávne základy a problémy aplikačnej praxe. Košice : Univerzita Pavla Jozefa Šafárika v Košiciach, 2018, s. 41 - 50

GREGOR, M. Právny postih korupcie v období Rímskej republiky. In 6. slovensko-české stretnutie doktorandov a postdoktorandov. Trnava : Právnická fakulta TU, 2018, s. $47-63$

HORVAT, M. Administratívna zodpovednost' právnických osôb, Bratislava : Wolters Kluwer, 2017, 263 s.

JELÍNEK, J. Trestní právo procesní - minulost a budoucnost. Praha : Leges, 2016, $440 \mathrm{~s}$.

studie. Praha : Karolinum, 2007, s. 9-18; tiež GREGOR, M. Inštitút odvolania vo formulovom a v kogničnom procese. In Pôžička či úžera? Nútený výkon rozhodnutia - rímskoprávne základy a problémy aplikačnej praxe. Košice : Univerzita Pavla Jozefa Šafárika v Košiciach, 2018, s. 41-50.

${ }^{65} \mathrm{~K}$ tejto myšlienke $\mathrm{v}$ kontexte zásady subsidiarity trestnej represie pozri TIBITANZLOVÁ, A. MULÁK, J. Ještě několik poznámek na téma zásady subsidiarity trestni represe. Trestněprávní revue, 2018, roč. 17 , č. 5 , s. $115-120$. 
KEISLER, I. Disciplinární odpovědnost osob ve služebním poměru. Časopis pro právní vědu a praxi, roč. XXIV, 2016, č. 4, s. 623-645

KMEC, J. - KOSÁŘ, D. - KRATOCHVÍL, J. - BOBEK, M. Evropská úmluva o lidských právech. Komentár̆. 1. vydanie. Praha : C. H. Beck, 2012, 1696 s.

KOŠIČIAROVÁ, S. Princíp ne bis in idem a správne trestanie. Princíp spravodlivosti v trestnom a správnom súdnom konaní. Pezinok : Justičná akadémia SR, 2016, 218 s.

LACIAK, O. Právo nebyt' stíhaný dvakrát za ten istý skutok (ne bis in idem) = Right not to be tried for the same offence (doublejeopardy). In JELÍNEK, J. a kolektiv: Ochrana zákládních práv a svobod v trestním řízení. Praha : Leges, 2020, s. 119 - 126

LALÍK, T. Právo na spravodlivý súdny proces a zásada ne bis in idem podl'a Dohovoru a správne trestanie. Justičná revue, roč. 67,2015 , č. 12, s. $1381-1402$

LINDGEN, E. Handbuch des Disziplinarrechts für Beamte und Richter in Bund und Ländern. Berlin : De Gruyter, 1968, 1264 s.

MACHAJOVÁ, J. a kol. Všeobecné správne právo. 5. aktualizované vydanie. Bratislava : Eurokódex, 2010, $688 \mathrm{~s}$.

MILUČKÝ, J. Správne trestanie očami nového Správneho súdneho poriadku. Princíp spravodlivosti v trestnom a správnom súdnom konaní. Pezinok : Justičná akadémia SR, 2016, 218 s.

MITSILEGAS, V. EU Criminal Law After Lisbon. Rights, Trust and the Transformation of Justice in Europe. Oxford : Hart Publishing, 2018, 336 s.

Príručka judikatúry ESL'P. Právo nebyt’ opakovane súdený alebo trestaný (preklad B. Babáková) In Bulletin oddelenia dokumentácie, analytiky a komparatistiky Kancelárie Najvyššieho súdu Slovenskej republiky, S. $46-57$

REPA, O. Totožnost' skutku a skutková veta v trestnom práve. Justičná revue, roč. 66, 2014, č. 6 - 7, s. 815 - 821

ŠAMKO, P. Daňové podvodné konania a ich dokazovanie. Bratislava : Wolters Kluwer, 2015, $419 \mathrm{~s}$.

SKŘEJPEK, M. Litem suam facere. In: Právněhistorické studie. Praha : Karolinum, 2007, s. 9 - 18.

SVÁK, J. - PITEK, L. Ne bis in idem v športe? Justičná revue, roč. 61, 2019, č. 1, s. 1 - 14.

THOMAS III, G. C. Double Jeopardy. The History, the Law. New York : New York University Press, 1998, $355 \mathrm{~s}$.

TIBITANZLOVÁ, A. - MULÁK, J. Ještě několik poznámek na téma zásady subsidiarity trestní represe. Trestněprávní revue, roč. 17,2018 , č. 5 , s. $115-120$

VRABKO, M. a kol. Správne právo hmotné. Všeobecná čast'. Bratislava : C. H. Beck, 2012, 480 s.

\section{ERRÁTA \\ $v$ č. 5/2020}

na s. 387 hore pri mene Čunderlík:

* má byt' Č u n d e r 1 í k, L., namiesto Čunderlík, J.

na s. 418 dole, namiesto textu:

* JUDr. Mgr. Marián K r o p a j, PhD., Ústav štátu a práva SAV, Bratislava. má byt' správne:

* Prof. JUDr. Mária S r e b a l o v á, PhD., Katedra správneho a environmentálneho práva, Právnická fakulta Univerzity Komenského v Bratislave.

Za uvedenú tlačovú chybu sa čitatel'om, ako aj autorom hlboko ospravedlňujeme redakcia časopisu Právny obzor 